\title{
Reflective Judgement and Prudential Rationality: A Contribution to an Inclusive Practical Application of Law
}

\author{
Maria Lúcia de Paula Oliveira ${ }^{1,2}$ [D
}

Published online: 6 November 2019

(c) The Author(s) 2019

\begin{abstract}
Hannah Arendt has developed a theory of the importance of judgment of taste for political manners, founded on the Kantian aesthetic theory. Nowadays this theory is considered a current theoretical reference for establishing a political way to reconcile the demands of the radicalization of deliberative democracy with the need for political inclusion (Iris Marion Young, Seyla Benhabib). Albena Azmanova in her The Scandal of Reason: A Critical Theory of Political Judgment proposes an inclusive political rhetoric. The political theory founded on judgment is based on Kant's philosophy; it was developed by Arendt and has greatly influenced the current debate, as an alternative theory in which the moral basis of law can be more sensitive to human contexts; a universalist theory more adequate for dealing with the tragic dimension of human life. The theory of political judgment uses the concepts of reflective judgment and 'enlarged thought' as its main concepts. As a starting point, a theory like this considers the singular judgments of justice that each person makes. The background, therefore, is not a rational foundation of principles, but the capacity of rational beings to make judgments. This post-metaphysical theory of law, based on a theory of judgment, is a critique of legal positivism, but presents itself as an alternative to the idealistic theory of law. But this theoretical project has received some criticism related to the adequacy of Arendt's rereading of Kantian philosophy and her attempt to approximate Kant's reflective judgment to the Aristotelian concept of phronêsis. Some critics, such as Bryan Garsten, believe that Kant's rhetoric of public reason diminished and displaced the prudential faculty of judgment that Arendt is to be interested in reviving. Arendt's attempt to find a theory of judgment in Kant's aesthetic theory is not successful, in Garsten's view. Our purpose is to show that a critical theory of judicial judgment is not only possible, but necessary; Arendt's theory of judgment offers an important contribution to a critical theory of judicial judgment, particularly one devoted to the construction of a legal theory that prioritizes a politics of social inclusion. This theory proposes a critical approach to the project of the procedural conception of democracy, since it can mask social exclusion. An adequate understanding of judicial argumentation cannot forget that it happens in a rhetorical context: it is not only important what a discourse says,
\end{abstract}

Extended author information available on the last page of the article 
but how it says it. The radicalization of deliberative democracy supposes a revision of the ways judicial deliberation is thought: not by reference to universal or at least general principles, but taking into consideration what is 'critically relevant', with a view to remedying social injustice (following Azmanova).

Keywords Kant · Arendt · Judgment $\cdot$ Law $\cdot$ Rhetoric $\cdot$ Justice

Hannah Arendt developed a theory on the importance of the judgment of taste for political manners, based on the Kantian aesthetic theory. Thus, following Kant's theory of reflective judgment, as interpreted by Hannah Arendt, this paper proposes a theory of political judgment. It is with the Critique the Power of Judgment that the power of judgment becomes one of Kant's central concerns. For Kant, judgment of taste is the best model of reflective judgment, which is the opposite of determinant judgment. Our aim is to demonstrate how a theory of political judgment, inspired by Kant and Arendt, could be useful in the search for an inclusive practical application of law. Law is rhetorical and argumentative; there is no great dispute on this issue. But what kind of communication is subjacent to the practice of law? When reflecting on the issue of political justice, considering the point of view of the judgment could be a good way to renew the importance of prudential rationality in the arena of law.

From the perspective of the theory of the judicial judgment, such judgment should be viewed as political: these judgments would bring rationality to bear, but that rationality does not elide the importance of feelings (or emotions), which are essential to the process of judgment. Adequate importance must be attributed to the emotions or to feelings in the activity of human beings. Moreover, the singularity of aesthetic judgment does not rule out the appeal to universal validity. It is true that the eventual universality of the judgment in this case is the hope of the one who pronounces it, rather than a truth whose validity is assented to on the basis of aprioristic principles. But the universal validity that is attained, even if it is less 'cogent', comes from the effort made by the one who judges to use 'communal sense', i.e. 'thinking in the position of everyone else'.

Some important notions are established by Kant in the Critique of the Power of Judgment. Aesthetic judgments are singular because they are reflective judgments. Moreover, for aesthetic judgment to be pure, it is essential that the subject not be interested in the existence of the object, whether that interest concerns the knowledge, morality or the utility of the object. The absence of interest underlying aesthetic judgment does not mean indifference or contempt for what it is being judged, but that for aesthetic judgment there is supposed to be a distance between the subject and the object being judged: something is not judged beautiful or sublime once the subject is concerned with its utility, its qualities or its moral correction. The hope contained in aesthetic judgment (the best model of reflective judgment) with regard to its universalization derives precisely from this appeal to the 'communal sense'. It is not, therefore, a utopia or the dream of the one who pronounces the judgment, but a hope based on communicative activity with the others (how else would it be 
possible to think in the place of the other, if not through the process of communication-the 'usage of public reason', as Kant put it).

A theory of a judicial judgement would guide the validity of these judgments with a very similar criterion: that which is judged to be just, is just for the one who judges; but the one who judges intends that the judgment should be for all, and that intention comes from the relationship of the one who judges with other people. The imagination also becomes relevant and turns to be not only a reproducer, but also a producer, as Hannah Arendt reminded us. The imagination produces concepts which cannot be the objects of knowledge, thus, there is an activity involving 'concepts' that does not produce knowledge. At this point, it is worthwhile recalling the wellknown passage from the Critique of the Power of Judgment:

"If the universal (the rule, the principle, the law) is given, then the power of judgment (... it provides the conditions a priori in accordance with which alone anything can be subsumed under the universal) is determining. If, however, only the particular is given, for which the universal is to be found, then the power of judgment is merely reflecting" [5:66]. The notion of sensus communis is of great importance. It implies that we must 'think in the position of everyone else', or to enlarge thought. The maxims of the understanding would therefore be three in number: 'to think for oneself', 'to think in accord with oneself' and 'to think in the position of everyone else'. The subjects who keep thinking for themselves become free from prejudice and superstition. Consistent thinking presupposes that subjects are self-vigilant and watch what they do when examining inside themselves, whereas "enlarged thought" supposes an abstraction from private conditions, with thoughtful consideration of the judgment from a universal viewpoint. Arendt views this as one of the most relevant contributions Kant made in the Critique of the Power of Judgment.

One cannot deny Hannah Arendt's insight in drawing attention to the importance of the Critique of the Power of Judgment for political philosophy. One of Kant's ideas which is of particular interest to Arendt is the "unsociable sociability" of human beings: the idea that human beings should live together, despite all the difficulties that this entails. The relationship between philosophy and politics is one of the themes of evident importance to political philosophy. Arendt opposes the tradition which places philosophy in a privileged position in relation to politics. This tradition would include Plato, Aristotle, Spinoza and even Hobbes, in her evaluation. When it comes to Kant, his philosophy would be paradoxical. On the one hand, Kantian melancholy, expressed in the difficulty and dislikes of human life, would demonstrate what could be an "unnoticed proximity" with the Greeks. In Kantian philosophy, the overcoming of that melancholic disposition would take place, at first, through the notion of progress in history-a non-individual one (Arendt does not show any admiration for Kant's historical teleology). Secondly, the mitigation of Kantian melancholy is grounded in the moral dignity of the human being as a moral being, which is an end in itself. The freedom of a human being, who lives in the world with other talented human beings equipped with common sense, is precisely the object of the first part of the Critique of the Power of Judgment. Kant's position concerning the relationship between philosophy and politics could be included in a tradition different from the one that defends the superiority of philosophy over politics; and this is evidently the focus of Arendt's interest. 
In contrast to Plato, for instance, true knowledge for Kant supposes sensibility, as he shows in the Critique of Pure Reason. Furthermore, the evaluation of the morality of actions is not exclusive to erudite philosophers, as he presents in his main works in moral philosophy, such as the Groundwork of the Metaphysics of Morals. In Kant's view, erudition or formal education, rather than facilitating evaluation of the morality of actions can actually complicate it. For Kant, philosophy should not be an activity addressed an elect—a privileged minority—but must be (or become) accessible to all. Therefore, Kant's political philosophy, in contrast to others, does not intend to give principles on the basis of which human beings can organize their lives in a community; rather he intends to investigate the reasons which drive them to enter into association, and how this association can be made perfect, on the basis of the same given reasons. The core notion to this purpose would be the public use of reason', where political freedom would be grounded, according to the author of What is the Enlightenment? The freedom of communication would also imply the willingness to listen and to be listened to. Not only does this mean impartiality in relation to other human beings, but 'enlarged thought' would presuppose being among other human beings in order for there to be judgment: there cannot be judgment from a privileged viewpoint, from a higher level. Its purpose would be, in the beautiful words of Arendt, "to train its own imagination to go visiting" [1:43]. Thus this 'enlarged thought', it must be said, would not embrace an extended empathy, by means of which we would want to put ourselves in the place of the others, that is, a passive reception of the thought of the other. In the context of the Lessons on Political Philosophy of Kant, which summarizes Hannah Arendt's lessons on the importance of the Kant's theory of judgment for political philosophy, we can find a return to the analogy of the spectator's viewpoint. The 'citizen of the world' - a viewpoint on which the cosmopolitism of the world was founded, would actually be a spectator of the world. This position is well illustrated in Kant's judgment of the French Revolution, as Arendt reminds us. She mentions Kant's opposition to revolutions, to the right to rebel, and to war. But, with regard to these issues, the same Kant expresses himself in a different way when analyzing them through the eyes of the spectator, who judges not morally, but from the viewpoint of the sense that underlies the historical process taking place. Kant was able to express admiration for what was going on with French Revolution.

The spectator is always a singular person, and contemplation is a solitary activity. However, contemplative activity does not elide the need for the public sphere, which is inherent in politics both for Kant and Arendt. Turning to Kant's aesthetic judgment, Arendt resumes his distinction between genius and taste, and she reaffirms Kant's position which argues in favor of the preeminence of taste over genius: "The public domain is made of critics and spectators, not of actors and creators" [1: 63]. And the power of judging what is right or wrong belongs to common sense, grounded in aesthetic judgment. The communicability of aesthetic judgments would depend on imagination, which, by means of reasoning, makes present that which was absent. Therefore, to judge well it is necessary to keep a distance: the one who is in the middle of a revolutionary process, for instance, would not be in condition to judge well. The criterion is then a kind of communicability or public sphere that brings out a sense common to all. 
How then, from the singularity of the spectator's judgment can one reach a 'mysterious' generalization? One of the answers would be in the idea of an original agreement of human kind, that is, the notion of Humanity. Things without finality would be precisely aesthetic objects and human beings themselves; therefore, there is a confluence of the theory of reflective judgment with the judgment of human actions; towards political judgment. Another relevant notion would be that of exemplary validity, which is constant in the third Critique. The procedure is to take something judged to be the best possible and make it a model of how things should be. The power of the model (example) comes from its effective existence in the world and its durability, but also from its temporality (one can find a better model at some time). Thus, by the 'the power of the example' there could be an exemplary universalism, which does not come from a universal principle, but from the contingence of singular judgment concerning what is just, which supposes a 'thinking in the position of everyone else', that is, an 'enlarged thought'.

The judgment of political justice, which is singular, presupposes a feeling of justice or injustice in face of something. As a matter of fact, the singular nature of a judicial judgment (following the model of aesthetic judgment, which is reflective) is not thus an obstacle to the hope for universalization. This is due to the fact that when judging something to be just, it is done with the consideration that all other people could also judge it to be just ('common sense' or 'communitarian sense'):

"To come back to what we said before: One judges always as a member of a community, guided by one's community sense, one's sensus communis. But in the last analysis, one is a member of a world community by the sheer fact of being human; this is one's 'cosmopolitan experience'. When one judges and when one acts in political manners, one is supposed to take one's bearings from the idea, not the actuality of being a world citizen and, therefore, also a Weltbetrachter, a world spectator" [1: 76].

Besides this, the viewpoint of judgment brings the human capacity to thinkwhich is not exclusive to philosophers, as both Kant and Arendt teach us-to politics. The judgment of justice presupposes the consideration of the common history of everybody involved in the 'search for a destiny'. This 'search for a destiny' does not mean a predetermination of human attitudes, but a search - by human beingsfor a sense to their actions and, this way, the judgment of justice is much more than an overwhelming feeling.

Nowadays, this theory is considered to be a current theoretical appeal to establish a political way of reconciling the demands pertaining to the radicalization of deliberative democracy with the need for political inclusion (Iris Marion Young, Seyla Benhabib). Albena Azmanova's A Critical Theory of Political Judgment proposes an inclusive judicial rhetoric. It has greatly influenced the current debate, as an alternative theory in which the moral basis of law can be more sensitive to human contexts; a universalist theory more adequate for dealing with the tragic dimension of human life. A Theory of Political Judgment uses the concepts of reflective judgment and 'enlarged thought' as its main concepts, and considers as a starting point the singular judgments of justice that each person makes. Therefore, the background is not a rational foundation of principles, but the capacity of judgment which rational beings are equipped with. 
Warning against the normative assumptions that are ontologically presupposed in other theories (which happens in the political theories of Jürgen Habermas and John Rawls), Azmanova develops a theory which is based on the character of norms and the form of institutionalization in the structure of social relations. This theory considers the social embeddedness of individuals and the structural sources of inequality, domination, and conflict. The starting point is not an impartial point of view, but the concrete experience of suffering, and a claim to the reduction of experienced injustice. At the same time, the normative order of society is politically defended and contested. Individuals live between conflict and cooperation, and that is the way we can judge something as just. The idea of consensus is substituted for the idea of political disagreement that supposes the hermeneutical concordance of the elements of disagreement. There is a minimally shared pre-understanding that consists, in her words, "in an agreement on what the relevant issues in contests over justice are" [2: 117]. This matrix of relevance is not connected with the content of justice claims, but rather to their coding (the "articulation of reference points and conceptual distinctions in which arguments are formulated as being comprehensible to all participants") [2: 117]. These codes are "phronetic", "because the signification of distinctions that orient understanding of what is relevant can be grasped only through experience; understanding the code is a matter of practical wisdom" [2: 158]. This phronetic constitution of public reasons constitutes the first degree of political criticism; the second source is the 'enlarged mentality', when it emerges from the normative issues as a result of discursive confrontations with the perspectives of others. But the third one, which constitutes judging as a critique of ideology, discloses the structural sources of injustice. Inspired in Arendt, she discusses the conditions of public deliberations in terms of the dialectics of seeing- “...the way we, as participants in the 'public spectacle', orient our judgement according to what we discern as relevant or noteworthy" [2: 231]. What makes the debate on controversial issues of justice possible is the existence of a tacit agreement in terms of what is relevant for dispute. There is a unity of communicative disagreement, which presupposes this preexistent agreement. 'Common sense', as proposed by Kant and Arendt, is very uncommon in shared social life; what we need to account for is a process of making sense in common, in the course of political contestation, Azmanova argues. Arendt oscillates between a notion of common sense as a situated one, based on a community of spectators and another notion, more abstract, that presupposes a universal human capacity. Azmanova believes that the best notion is the situated one. However, there is a good way of dealing with the oscillation: maybe the two alternatives are not exclusive and they allow us to imagine a contextual universalism in a world with so many differences and even conflicts. It is possible to think that juridical rhetoric is compatible with this theory of political judgment, and that it is one we could recommend to someone that intends to search for a way to make a judicial system more inclusive.

Defending inclusive rhetoric, Iris Marion Young reaffirms that: "A theory of democratic inclusion requires an expanded conception of political communication, both in order to identify modes of internal inclusion and to provide an account of more inclusive possibilities of attending to one another in order to reach understanding" [7: 56]. What is proposed here is a concept of rhetoric that assumes a distinction 
between what a discourse says, i.e. its substantive content or message, and how it says it. Emotions, the use of figures of speech, non-verbal forma of making a point, involve paying attention to the particular audience one is communicating with, and orienting one's claims and arguments to the particular assumptions, history and idioms of that audience. This situated and affective appeal of rhetoric makes the move from thinking to committed action possible, which is what political judgment involves: "Rhetoric motivates the move from reason to judgment" [7: 69].

A post-metaphysical theory of law, based on a theory of judgment, is a critique of the theory of legal positivism, but presents itself as an alternative to the idealistic theory of law. But this theoretical project has met some criticism related to the adequacy of Arendt's rereading of Kant's philosophy and her attempt to approximate Kant's reflective judgment to the concept of phronêsis. Some critics, such as Bryan Garsten, believe that Kant's rhetoric of public reason diminished and displaced the prudential faculty of judgment, which Arendt seems interested in reviving. In Garsten's view Arendt's attempt to find a theory of judgement in Kant's aesthetic theory is not successful. He resisted Arendt's attempt to reread Kant's theory of aesthetic judgment in political terms and recalls that in The Crisis in Culture, Arendt explicitly linked judgment and persuasion; she drew on Cicero's writing on rhetoric to identify connections between practical judgment and modes of judgment appropriate for political action. For Garsten, Kant's use of the notion of 'sensus communis' cannot be read as a 'comunitarian sense', as was proposed by Arendt. For Kant, he argues, this notion did not refer to actual communities. Garsten is not wrong about there being some differences between Kant's original concepts and the theoretical appropriation developed by Arendt. He suggests that a more detailed approach to Kant's philosophical system could result in a different comprehension of the empirical perspective of human life. The political texts and The Metaphysics of Morals could be important sources for an investigation of this kind. Anyway, it is important, at this point, to realize that Arendt's effort to combine elements of the Aristotelian model of the exemplary quality of the judgment of phronêsis with the Kantian model of reflective judgment is a relevant contribution to contemporary debates, exactly because it allows us to reconcile contextual judgments in human affairs with, at least, a plea for universalism [3: 195].

A critical theory of judicial judgment is not only possible, but necessary; Arendt's theory of judgment offers an important contribution to the critical theory of judicial judgment, particularly one devoted to the construction of a legal theory that prioritize the politics of social inclusion. This theory proposes a critical approach to the project of the procedural conception of democracy, since it can mask social exclusion.

Also, an adequate understanding of judicial argumentation cannot ignore the fact that it takes place in a rhetorical context: it is not only important what a discourse says, but how and why it says. The radicalization of deliberative democracy presupposes a revision of the ways a judicial deliberation is understood: not by reference to universal or at least general principles, but by taking into consideration what is 'critically relevant', in view of remedying social injustice.

In political theory that believes conflict is a part of the political system, disagreement is not occasional, but indispensable. Besson [4: 65] believes that taking 
disagreement seriously is also crucial for taking legal indeterminacy seriously. She is not wrong, but if we want law to come together with the radicalization of democracy, then it is important to assume that there is no contradiction between the rule of law and the argumentative dimension of law. And it is also indispensable that rhetorical judicial practice can make explicit the process of political exclusion, thus preventing juridical institutions from perpetuating or aggravating social and political injustice. As MacComick [6] reminds us, a basic right, such as the right of action, only exists because people can disagree about rights. There is a confluence between the rule of law (and the juridical institutions that stabilize power) and the political conflict that justifies the constant need for revising the interpretation of law and improving judicial institutions. Judicial rhetoric is a special locus for pointing out political and social exclusion.

Open Access This article is distributed under the terms of the Creative Commons Attribution 4.0 International License (http://creativecommons.org/licenses/by/4.0/), which permits unrestricted use, distribution, and reproduction in any medium, provided you give appropriate credit to the original author(s) and the source, provide a link to the Creative Commons license, and indicate if changes were made.

\section{References}

1. Arendt, Hannah. 1982. Lectures on Kant's Political Philosophy. Chicago: Chicago University Press.

2. Azmanova, Albena. 2012. The Scandal of Reason-A Critical Theory of Political Judgment. New York: Columbia University Press.

3. Benhabib, Seyla. 2001. Judgment and Politics in Arendt's Thought. In Judgment, Imagination and Politics-Themes from Kant and Arendt, ed. Ronald Beiner and Jennifer R. Nedelsky. Lanham, MD: Rowman \& Littlefield Publishers.

4. Besson, Samantha. 2005. The Morality of Conflict-Reasonable Disagreement and the Law. Oregon: Oxford and Portland.

5. Kant, Immanuel. 2000. Critique of The Power of Judgment (trans: Paul Guyer and Eric Matthews). Cambridge: Cambridge University Press.

6. MacCormick, Neil. 1995. Rhetoric and the Rule of Law. Oxford: Oxford University Press.

7. Young, Iris Marion. 2000. Inclusion and Democracy. Oxford: Oxford University Press.

Publisher's Note Springer Nature remains neutral with regard to jurisdictional claims in published maps and institutional affiliations.

\section{Affiliations}

\section{Maria Lúcia de Paula Oliveira ${ }^{1,2}$ [D}

Maria Lúcia de Paula Oliveira malup@hotmail.com

1 Federal University of the State of Rio de Janeiro, Rio de Janeiro, Brazil

2 Pontifical Catholic University of Rio de Janeiro, Rio de Janeiro, Brazil 